\title{
ADAPTIVE POWER CONTROL ON DVB-T SYSTEM BASED ON NO- REFERENCE PERCEPTUAL PICTURE QUALITY METRIC
}

\author{
* Randy Rahmanto ${ }^{1}$, Belinda Ayuningtyas ${ }^{2}$ \\ ${ }^{1,2}$ Fakultas Teknik dan Informatika, Program Studi Teknik Elektro, Universitas Dian Nusantara, Jakarta, Indonesia
}

*Email Korespondensi:

randy.rahmanto@undira.ac.id

\section{ARTIKEL INFORMASI}

Diterima:

3 March 2021

Direvisi:

15 April 2021

Dipublikasi:

16 Mei 2021

\begin{abstract}
ABSTRAK
Digital Video Broadcasting - Terrestrial (DVB-T) adalah salah satu standar broadcast televisi digital di eropa. Ketika mentransmisikan data melalui sistem DVB-T, noise merupakan masalah yang tidak dapat dihindarkan. Masalah tersebut dapat menyebabkan penurunan kualitas video yang diterima oleh end user. Berdasarkan penjelasan diatas, penulis mendesain sebuah adaptive power control on DVB-T system based-on noreference perceptual picture quality metric yang dapat menentukan berapa banyak transmit power yang dibutuhkan oleh receiver untuk mendapatkan hasil kualitas video yang baik. No-reference image metric akan digunakan untuk membuat visual quality feedback di sisi receiver. Hasil dari image metric ini berupa nilai dalam bentuk angka yang akan dikirimkan ke transmitter sebagai feedback. Di sisi transmitter, ada explicit link adaptation yang mengatur power menggunakan perceptual quality (PQ-based) berdasarkan visual quality feedback. Hasil dari adaptive power control menunjukkan bahwa, ketika visual quality feedback menunjukkan angka dibawah 96 poin (unacceptable quality), power akan dinaikkan sebesar $0.05 \mathrm{~dB}$ untuk meningkatkan kualitas video yang diterima. Sebaliknya, jika visual quality feedback menunjukkan lebih dari sama dengan 96 (acceptable quality), power akan diturunkan untuk menghemat biaya power cost. Adaptive power control memberikan hasil yang sangat baik karena secara signifikan dapat mengurangi nilai visual quality yang buruk pada simulasi dengan menggunakan power sebesar $18 \mathrm{~dB}$.
\end{abstract}

Keyword: Adaptive Power Control, No-reference Image Metric, Link Adaptation, DVB-T, Feedback

\section{PENDAHULUAN}

Di era digital ini, penggunaan televisi analog telah berubah menjadi digital televisi. Digital Video Broadcasting - Terrestrial (DVB-T) adalah salah satu standar Eropa untuk penyiaran televisi digital. Sistem ini mentransmisikan sinyal dari audio, video digital, dan data lain seperti MPEG. Saat transmisi data melalui sistem DVB-T, noise masih menjadi masalah yang tidak bisa dihindari. Berbagai macam interferensi, dispersi, difraksi dan Refleksi akibat cuaca buruk dan berbagai macam obek yang telah dilalui oleh sinyal yang ditransmisikan. Masalah tersebut dapat menurunkan kualitas video yang diterima oleh user. Sebagai acuan kualitas gambar, komunikasi dua arah dalam sistem digital bisa menjadi solusi. Tidak seperti pada TV analog, 
Sistem receiver yang dirancang tidak hanya menerima sinyal dari transmitter, tetapi juga memberikan kualitas visual feedback berdasarkan kualitas video yang ditransmisikan.

Dari uraian di atas, metrik gambar non referensi akan digunakan untuk membuat kualitas visual feedback di sisi Receiver. Hasil dari metrik gambar ini adalah berupa point yang akan dikirimkan ke transmitter. Di transmitter, ada eksplisit link adaptation yang menerapkan power kontrol menggunakan kualitas perseptual (PQ-based) berdasarkan kualitas visual feedback yang diterima. Kontrol daya adaptif akan mengatur berapa banyak Power yang dibutuhkan oleh receiver untuk menerima kualitas video yang bagus.

Penelitian tentang "Adaptive Power Control on DBV-T System Based on No-Reference Perceptual Quality Metric" ini membatasi masalah bagaimana kinerja sistem DVBT melalui saluran AWGN, bagaimana menerapkan Feedback Channel untuk menyediakan status saluran informasi berdasarkan kualitas visual, bagaimana mengadaptasi daya transmisi berdasarkan kualitas visual

Tujuan dari penelitian ini adalah untuk melihat kemungkinan penggunaan kualitas visual feedback untuk link adaptation berdasarkan power control. Daya transmisi akan disesuaikan dengan kondisi saluran berdasarkan kualitas visual feedback dari receiver. Daya transmisi akan meningkat saat kondisi saluran sedang kurang baik dan daya pancar akan berkurang ketika kondisi saluran sedang baik.

Ruang lingkup penelitian ini adalah simulasi Digital Video Broadcasting Terrestrial (DVBT) pada platform simulink menggunakan AWGN Channel, SNR dan BER digunakan sebagai indikator kinerja. Blok simulasi memiliki feedback channel untuk memantau status channel pada receiver, indikatornya berupa kualitas visual yang didapat dari gambar yang diterima. Dari hasil feedback, pada sistem ini memiliki algoritma power control untuk secara otomatis menyesuaikan daya yang digunakan pada transmisi.

\section{KAJIAN PUSTAKA}

\section{Digital Video Broadcasting (DVB)}

Digital video broadcasting (DVB) telah menjadi data di seluruh dunia penyiaran. Layanan DVB telah diperkenalkan di Eropa, Amerika Utara dan Selatan, Asia, Afrika dan Australia. Teknologi ini memungkinkan untuk disiarkan "datacontainers " di mana semua jenis data digital hingga $38 \mathrm{Mbit} / \mathrm{s}$ datarate dan memiliki bit error rate mencapai $10^{-11}$. Digital video bradcasting dapat dikirimkan menggunakan media fisik satu atau lebih multipleks ditransmisikan misalnya: sistem satelit (DVB-S), Kabel (DVB-C) dan saluran terestrial dari satu titik pemancar (DVB-T). Model penyampaian layanan DVB dapat dilihat pada Gambar 1.

Gambar 1 menunjukkan bahwa jaringan DVB dapat dikirimkan dalam 3 median yang berbeda, itu akan menjadi multipleks. Bouquet adalah kumpulan jasa yang dipasarkan sebagai satu kesatuan. Dalam penelitian ini simulasi menggunakan sistem DVB-T sebagai sistem DVB model. Ini dipilih karena DVB-T merupakan layanan televisi digital gratis yang memungkinkan pengguna menerimanya dengan menggunakan alat penerima tambahan misalnya. set-top-box (STB), tidak seperti DVB-S atau DVB-C yang menyediakan layanan berbayar.

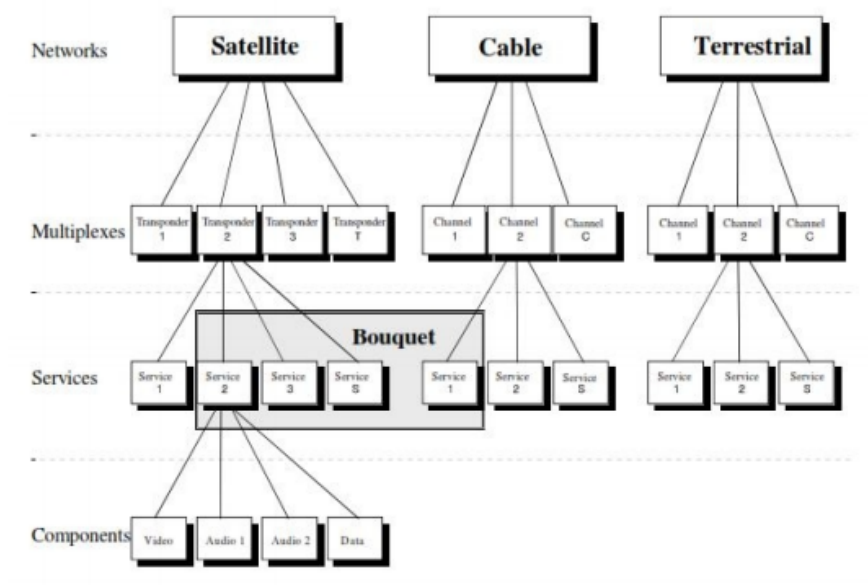

Gambar 1. Digital Broadcasting, Service Deliveri model Sumber: ETSI EN 300468 V1.7.1 


\section{Digital Video Broadcasting Terestrial (DVB-T)}

Digital video broadcasting terestrial (DVB-T) adalah standar Eropa untuk transmisi siaran televisi terestrial digital. Sistem DVB-T menangani siaran terestrial dari sinyal TV berkode MPEG-2. Oleh karena itu, adaptasi yang tepat dari aliran transports berkode digital ke karakteristik saluran terestrial yang berbeda diperlukan. Persyaratan ini menghasilkan sistem transmisi yang fleksibel menggunakan modulasi multi-carrier, yaitu yang disebut teknik Orthogonal Frequency Division Multiplex (OFDM). Koreksi kesalahan bersambung dapat dipisahkan dalam dua blok: pengkodean luar dan interleaving luar biasa digunakan pada Satellite dan Cable Baseline Spesifikasi dan pengkodean bagian dalam adalah umum untuk Satelit Baseline spesifikasi. Penggunaan interleaving bagian dalam dikhususkan untuk sistem DVB-T untuk mengakomodasi tingkat transmisi yang berbeda, selain lima tingkat kode, tiga jenis skema modulasi non-diferensial dapat dipilih: QPSK, 16-QAM dan 64-QAM. 16-QAM dan 64-QAM [4]. Standar sistem DVB-T bias terlihat pada Tabel 2.1

Tabel 1. Parameter DVB-T

\begin{tabular}{|c|c|}
\hline Input & MPEG-2 \\
\hline Modes & Constant coding \& modulation \\
\hline $\begin{array}{c}\text { Forward Error Correction } \\
(\text { FEC) }\end{array}$ & $\begin{array}{c}\text { Convolutional Coding + Reed Solomon } \\
1 / 2,2 / 3,3 / 4,5 / 6,7 / 8\end{array}$ \\
\hline Modulation & OFDM \\
\hline Modulation Schemes & $1 / 4,1 / 8,1 / 16,1 / 32$ \\
\hline $\begin{array}{c}\text { Guard Interval } \\
\text { Diescrete Fourier Transform } \\
\text { (DFT) }\end{array}$ & $2 \mathrm{k}, 8 \mathrm{k}$ \\
\hline
\end{tabular}

\section{Link Adaptasi}

Prinsip Link adaptasi adalah memilih parameter transmisi sedemikian rupa sehingga memaksimalkan kinerja untuk kondisi saluran tertentu berdasarkan waktu. Saat ini, teknik Link adaptasi untuk komunikasi Wireless didasarkan pada pengukuran konvensional seperti SNR, BER, FER atau kombinasinya sebagai indikator kualitas atau metrik.

Secara umum teknik Link adaptasi dapat diklasifikasikan menjadi dua kategori, ada Link adaptasi eksplisit dan Link adaptasi implisit. Teknik ini dapat dibagi lagi menjadi beberapa kategori. Hal tersebut dapat dilihat pada Gambar 2.

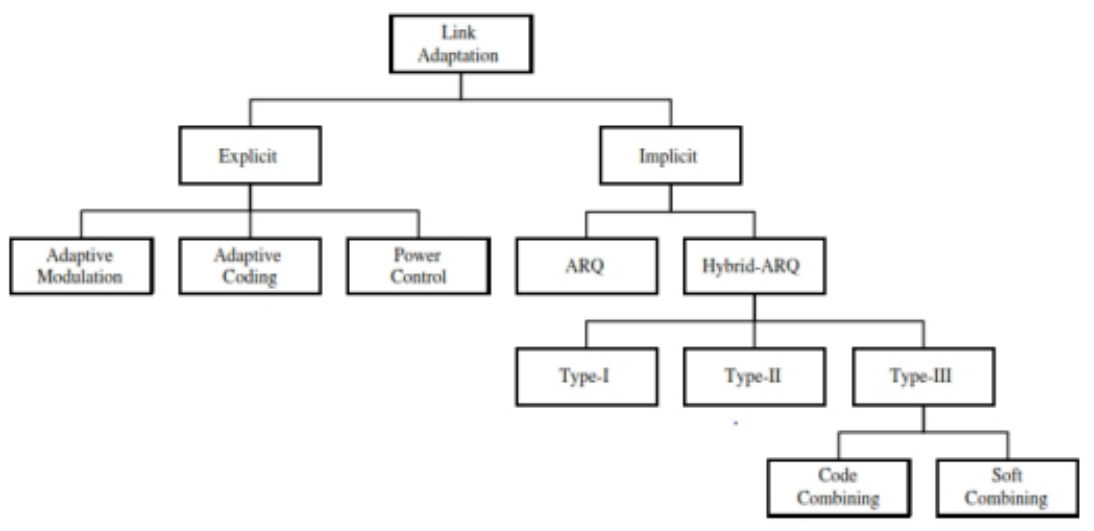

Gambar 2. Klasifikasi teknik adaptasi tautan.

Sumber: TM Kusuma, 2005. 
Gambar 2 menunjukkan bahwa adaptasi tautan diklasifikasikan menjadi dua kategori, di sana adalah Link adaptasi eksplisit dan implisit. Link adaptasi eksplisit dibagi menjadi tiga kategori, modulasi adaptif, pengkodean adaptif dan Power kontrol. Sedangkan Link adaptasi implisit dibagi menjadi ARQ dan hybrid ARQ. Hybrid-ARQ dibagi menjadi Tipe-I, Tipe-II, dan Tipe-III, di mana tipe tiga dibagi menadi penggabungan kode dan penggabungan Soft. Dalam penelitian ini, Link adaptasi eksplisit pada Power kontrol yang digunakan.

\section{Image Metric (Metrik Gambar)}

Metrik adalah ukuran yang memfasilitasi kuantifikasi beberapa hal karakteristik tertentu. Dalam pemrosesan gambar, metrik dapat diartikan sebagai ukuran untuk menilai kualitas suatu citra dengan menggunakan pendekatan kuantitatif. Secara umum, image metrik dapat diklasifikasikan menjadi tiga kelompok. Pertama, metrik melibatkan intervensi manusia sedangkan model matematika digunakan di kelommpok kedua, yang mudah diatur. Metrik ketiga menggunakan model matematis persepsi manusia. Sebuah angka image metrik telah diusulkan oleh para peneliti di seluruh dunia untuk lebih baik menilai kualitas gambar.

Dalam penilaian citra, ada banyak metode yang dapat diterapkan untuk mengukur kualitas gambar. Secara umum, metrik dapat dibagi berdasarkan apakah kualitas dihitung menggunakan keterlibatan manusia atau pemodelan matematika. Penilaian yang menggunakan keterlibatan manusia disebut penilaian subjektif, sedangkan yang menggunakan pemodelan matematika disebut penilaian obyektif.

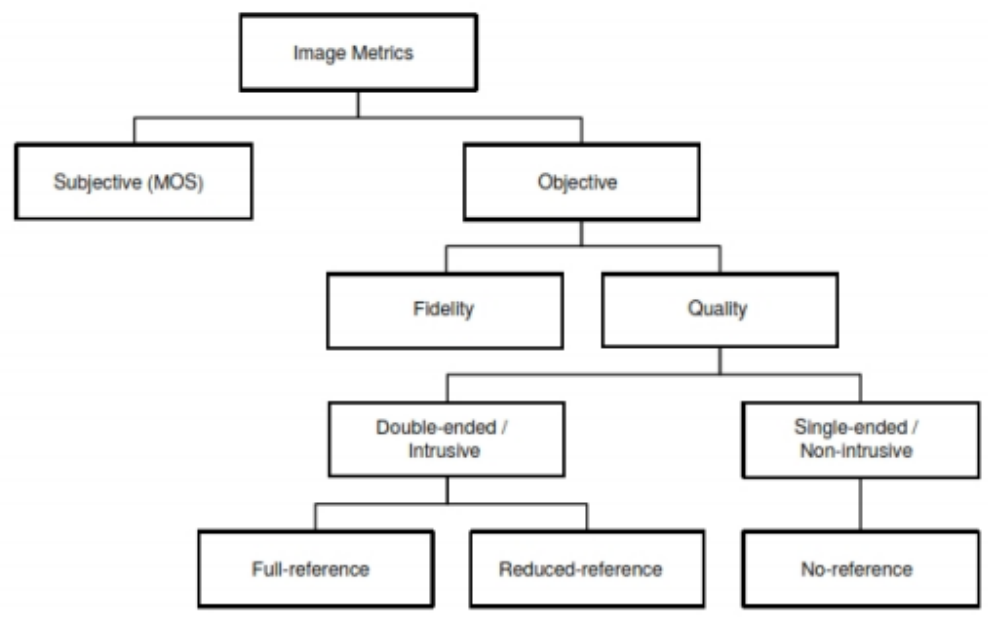

Gambar 3. Diagram klasifikasi Image metrik.

Sumber: TM Kusuma, 2005

Gambar 3 menunjukkan diagram klasifikasi metrik gambar. Ini dibagi menjadi subjektif ((Mean Opinion Score (MOS)) dan obyektif. ketetapan dan kualitas pada Image metrik yang objektif. Kualitas Image Metrik dibagi menjadi Double-Ended/intrusif yang memiliki image metrik referensi lengkap dan referensi tereduksi dan Single-Ended / non intrusive yang memiliki Image metrik tanpa referensi.

\section{MATLAB}

MATLAB atau laboratorium matriks adalah bahasa tingkat tinggi untuk ilmu pengetahuan dan komputasi teknik. Tampilan desktop disetel untuk eksplorasi berulang, desain, dan pemecahan masalah. Aplikasi ini memiliki fiture untuk pemasangan kurva, klasifikasi data, analisis sinyal dan banyak tugas khusus domain lainnya. Matlab memiliki add-on tool boxes atau berbagai aplikasi teknik dan ilmiah. Aplikasi ini juga punya alat untuk membangun aplikasi dengan antarmuka pengguna khusus. Antarmuka ke C / C ++, Java ${ }^{\circledR}$, .NET, Python ${ }^{\circledR}, \mathrm{SQL}$, Hadoop ${ }^{\circledR}$, dan Microsoft ${ }^{\circledR}$ Excel ${ }^{\circledR}$. Gambar 4 ditampilkan antarmuka MATLAB r2015b. 


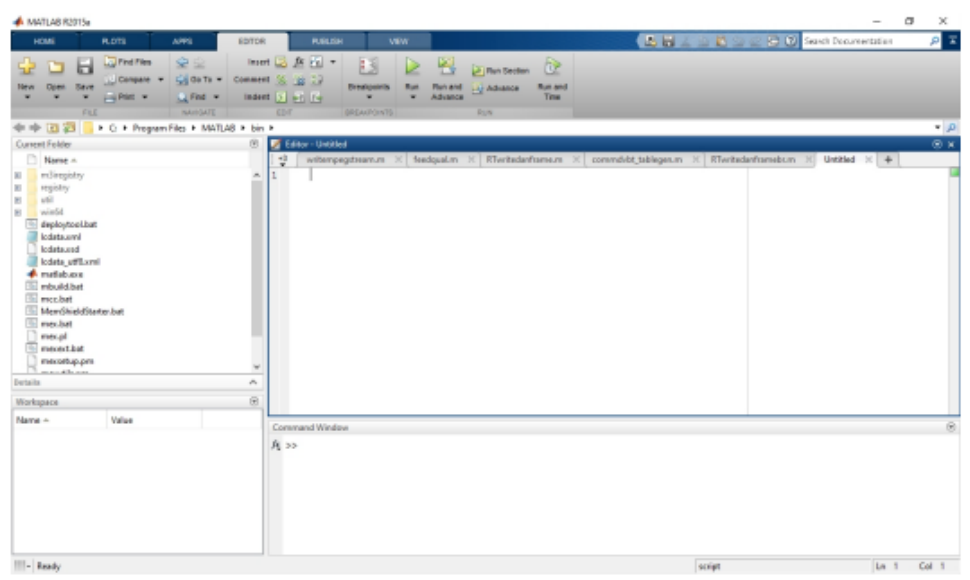

Gambar 4. Interface MATLAB r2015a

Gambar 4 menunjukkan antarmuka MATLAB r2015a. Ada folder saat ini yang mengakses file MATLAB, Command Window yang berfungsi untuk masuk perintah pada comman line, Workspace untuk mengeksplorasi data yang telah dibuat atau impor dari file dan editor untuk menulis program file *.m.

\section{METODE}

Metodologi penelitian merupakan tahap-tahap penelitian yang harus ditetapkan dahulu sebelum melakukan pemecahan masalah, sehingga penelitian dapat dilakukan dengan terarah dan memudahkan dalam menganalisis permasalahan yang ada. Berikut diagram alir Metode Penelitian yang digunakan dapat dilihat pada gambar 5 berikut :

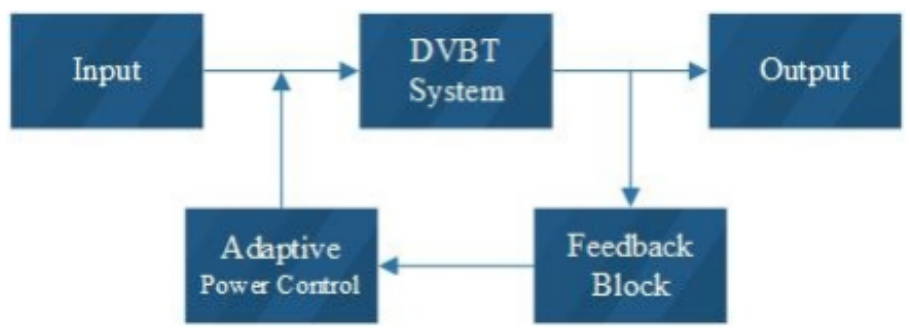

Gambar 5. Diagram alir proses penelitian.

\section{Sistem Input}

Dalam input sistem ini, file MPEG-2 akan diubah ukurannya menjadi 188 byte per file paket. Blok ini didasarkan pada program m-file matlab. Prosesnya bisa dilihat pada gambar 6 .

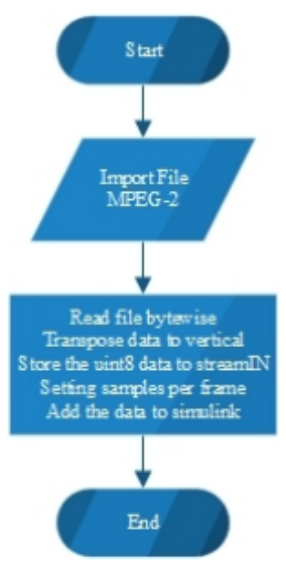

Gambar 6. Diagram Alir Sistem Input 
Gambar 6 menunjukkan bahwa proses dimulai dengan mengimpor file MPEG-2 lalu baca file tersebut juga. Data uint8 akan dialihkan dan disimpan di variabel streamIN di matlab. Dengan mengatur sampel per frame ke 188, Bentuk hasil dari proses ini adalah data berukuran 188x1 yang dapat ditransmisikan Sistem DVB-T pada simulink.

\section{Sistem DVB-T}

Sistem DVB-T terdiri dari beberapa blok yang berfungsi untuk menerapkan standar sistem DVB-T. Model yang diimplementasikan dipilih. Berikut parameter yang dapat dilihat pada tabel 2

Tabel 2. Parameter Simulink DVB-T

\begin{tabular}{|c|c|}
\hline Process in Schematic & Block in Simulink \\
\hline Outer Coder & $(204,188)$ Reed-Solomon Encoder \\
\hline Outer interleaver & Convolutional Interleaver, I =12 \\
\hline Inner coder & $(3 / 4)$ Convolutional Code \\
\hline Inner interleaver & DVB-T inner interleaver \\
\hline Mapper & 64 QAM Mapper \\
\hline OFDM & 2k Mode \\
\hline
\end{tabular}

Dengan menggunakan parameter diatas maka dibuat sistem DVB-T pada simulink matlab. Simulink matlab yang diimplementasikan dapat dilihat pada gambar 7 .

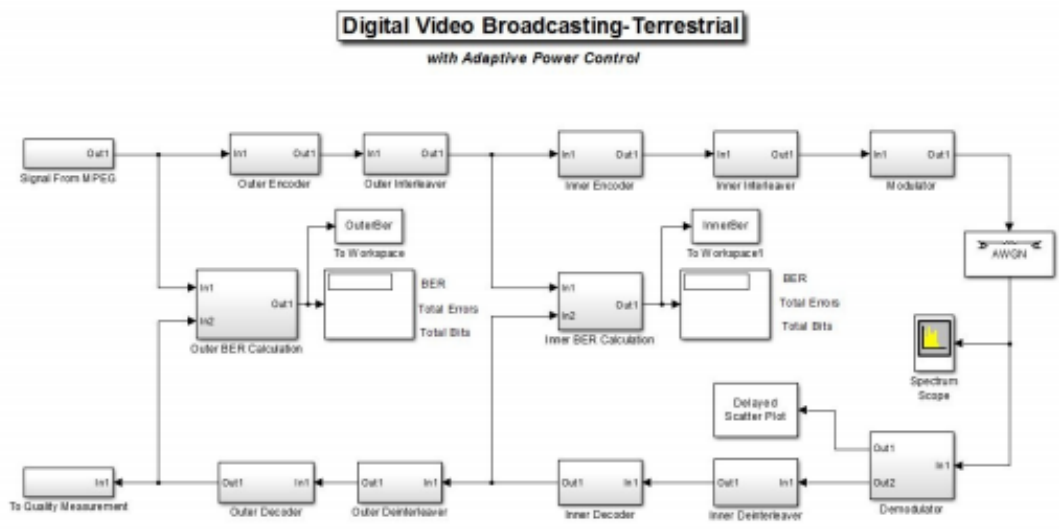

Gambar 7. Penyiaran Video Digital-Terestrial

Gambar 7 menunjukkan implementasi simulink dari blok fungsional pada Standar Digital Video Broadcasting Terrestrial (DVB-T) dan menyajikan model simulasi untuk sistem DVB-T menurut Standar ETSI EN 300744.

\section{Blok Feedback}

Tujuan dari feedback block ini adalah untuk menghasilkan kualitas visual dalam bentuk poin dari skala 0.00 sampai dengan 100.00 berdasarkan output yang diberikan oleh sistem DVB-T. Kualitas gambar diukur menggunakan Kualitas Prinsip Tanpa Referensi Assessment untuk mendapatkan kualitas visual dari setiap informasi frame yang dikumpulkan. Blok ini didasarkan pada program m-file Matlab. Proses blok umpan balik bias dilihat pada Gambar 8. 


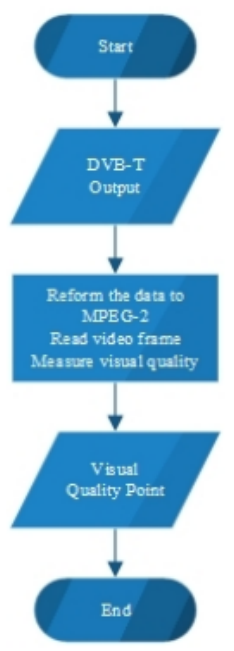

Gambar 8. Diagram alir proses Feedback

Gambar 8 menunjukkan bahwa proses pertama adalah mereformasi aliran data menjadi mpeg-2, kondisi ini dapat dicapai dengan memasukkan akhir file (eof) pada setiap file langkah waktu yang ditentukan saat simulasi berjalan. Setelah file sudah direformasi, frame video dari file mpeg-2 akan dibawa ke proses selanjutnya. Untuk Setiap frame yang telah diambil kualitas gambarnya akan diukur dengan No- Reference Preceptual Quality Assessment untuk mendapatkan kualitas visual setiap mengumpulkan informasi bingkai. Hasil dari proses ini adalah floating point dengan total 5 karakter angka termasuk 2 desimal dari 0,00 hingga 100,00.

Seperti yang kita ketahui, feedback ini ada di penerima. Untuk mengirim feedback ke pemancar, ada opsi berikut:

i. $\quad$ Frekuensi Radio, data dapat dikirim dengan menggunakan frekuensi radio

ii. GPRS, built in gprs dapat digunakan untuk mentransfer hasil dari receiver ke pemancar melalui internet.

Kedua opsi tersebut dapat digunakan untuk mengirimkan hasil kualitas visual .. Jika menggunakan radio frekuensi, membutuhkan lebih banyak biaya dan ruang untuk membuat sistem frekuensi radio pada DVB-T Receiver. Dengan menggunakan opsi kedua, banyak provider yang sudah memiliki file sistem jaringan. Ini dapat digunakan untuk mengirim data kualitas visual dengan menggunakan modem bawaan pada penerima DVB-T. Data hasil terdiri dari 5 karakter yang artinya hanya perlu 32 bit atau 4 byte data yang perlu ditransfer. Sehingga dibutuhkan bandwidth yang tidak terlalu besar artinya dapat menekan biaya tambahan.

\section{Blok Adaptif Power Control}

Blok power kontrol adaptif terletak pada pemancar DVB-T. Dengan menggunakan kualitas persepsi (PQbased) kontrol daya, blok ini memiliki kemampuan untuk secara otomatis mengontrol daya pada pemancar berdasarkan visual yang diterima umpan balik berkualitas. Blok ini didasarkan pada program m-file Matlab. Yang adaptif Proses pengendalian daya dapat dilihat pada Gambar 9

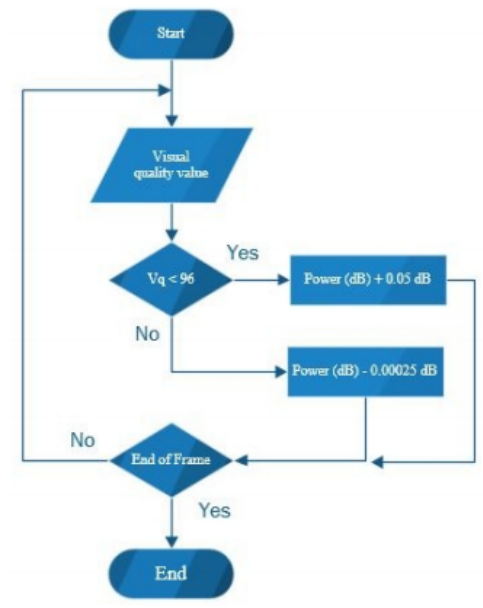


Gambar 9. Diagram alir proses adaptif power control

Gambar 9 menunjukkan bahwa proses ini didasarkan pada nilai kualitas visual itu telah diterima. Ketika kualitas di bawah 96 poin, daya akan menjadi meningkat sebesar $0,005 \mathrm{~dB}$, jika kualitasnya sama atau lebih dari 96 poin, daya akan berkurang $0,00025 \mathrm{~dB}$. Ambang 96 poin dipilih Karena bila gambar memiliki kualitas visual lebih dari 96 poin, gambar tersebut kualitas dalam keadaan baik (dapat diterima) berdasarkan persepsi manusia. Jika tidak, bila kualitas visual kurang dari 96 poin, kualitas gambar tidak dapat diterima.

Dengan menggunakan blok kontrol daya adaptif ini, ia dapat menilai video yang diterima baik atau buruk dengan menggunakan umpan balik kualitas visual. Kekuatan dapat beradaptasi meningkatkan daya untuk meningkatkan kualitas visual saat kualitas video buruk. Juga dapat secara otomatis mengurangi daya, ketika kualitasnya sudah bagus untuk disimpan lebih banyak biaya daya.

\section{HASIL DAN PEMBAHASAN}

\section{Simulasi Tanpa Adaptasi Power Kontrol}

Simulasi akan dijalankan beberapa kali tanpa menggunakan Eb / No (dB) yang berbeda mengadaptasi kontrol daya. Simulasi dilakukan untuk mengumpulkan BER dan titik kualitas visual Feedback. Konfigurasi simulasi dapat dilihat pada Tabel 3.

Tabel 3. Konfigurasi Simulasi Feedback

\begin{tabular}{|c|c|}
\hline No & Power $(\mathrm{dB})$ \\
\hline 1 & 18 \\
\hline 2 & 18.1 \\
\hline 3 & 18.2 \\
\hline 4 & 18.3 \\
\hline 5 & 18.4 \\
\hline 6 & 18.5 \\
\hline 7 & 19 \\
\hline 8 & 19.5 \\
\hline 9 & 20 \\
\hline
\end{tabular}

Tabel 4.1. menunjukkan bahwa simulasi akan dijalankan 9 kali dengan menggunakan perbedaan Konfigurasi Eb / No (dB) di AWGN Channel.

\section{Hasil Umpan Balik Kualitas Visual}

Hasil dari setiap percobaan dapat dilihat pada Gambar 10 (18 dB), Gambar 11 (18.1 dB), Gambar 12 (18.2) dB, Gambar 13 (18.3 dB) dan Gambar 14 (18.5 - $20 \mathrm{~dB})$.

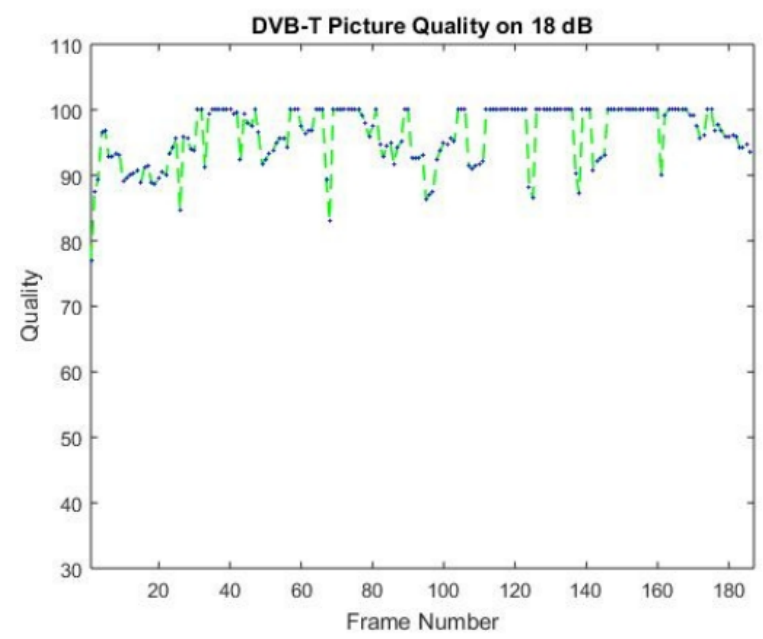


Gambar 10. quality verse frame number $(18 \mathrm{~dB})$

Gambar 10. ditampilkan hasil kualitas feedback frame number $18 \mathrm{~dB}$. Video yang di-streaming memiliki kualitas yang buruk hampir di setiap frame saat power mencapai $18 \mathrm{~dB}$.

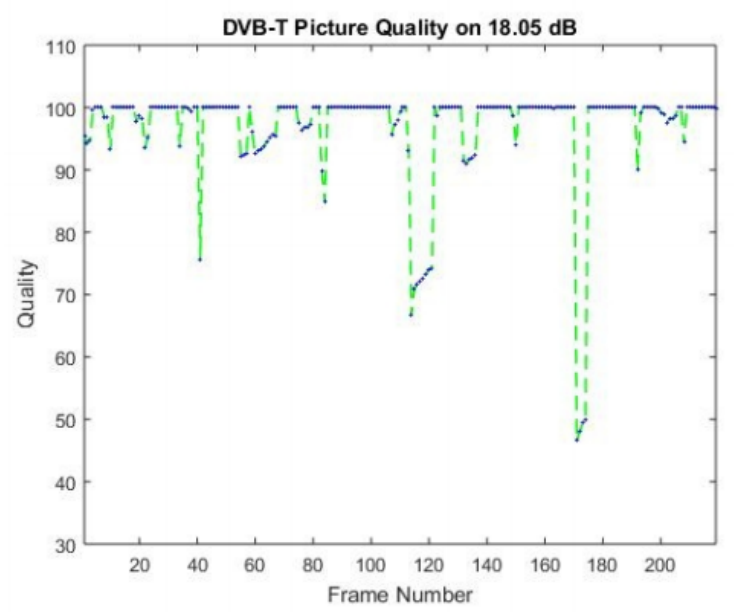

Gambar 11. quality verse frame number $(18.05 \mathrm{~dB})$

Gambar 11. ditampilkan hasil kualitas feedback frame number 18.05 dB. Kualitas memberikan kelompok kesalahan yang berbeda dibandingkan dengan hasil $18 \mathrm{~dB}$. Itu punya kurangi kelompok kualitas buruk tetapi ada kesalahan dengan kualitas sangat buruk aktif frame number 171 yang memiliki nilai kualitas 46,67. Ini adalah nilai kualitas terburuk di percobaan ini.

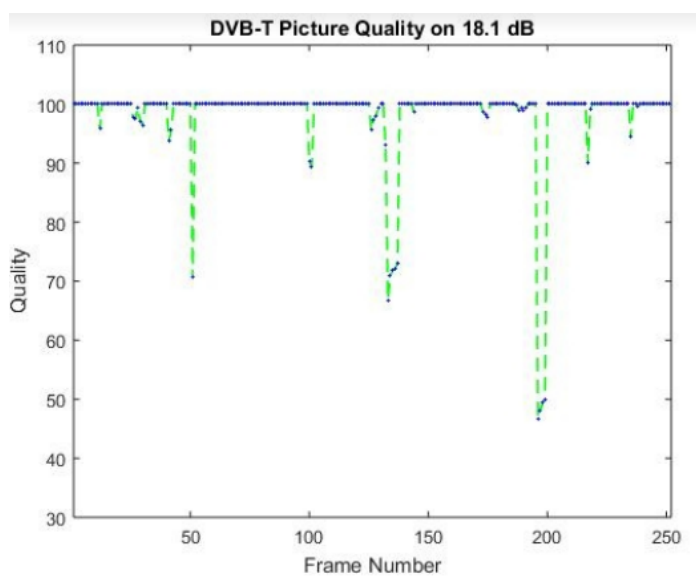

Gambar 12. quality verse frame number $(18.1 \mathrm{~dB})$

Gambar 12. ditampilkan hasil kualitas feedback frame number $18.1 \mathrm{~dB}$. Video yang distreaming masih memiliki banyak kelompok dengan kualitas buruk, tetapi ada pengurangan jumlah kejadian itu.

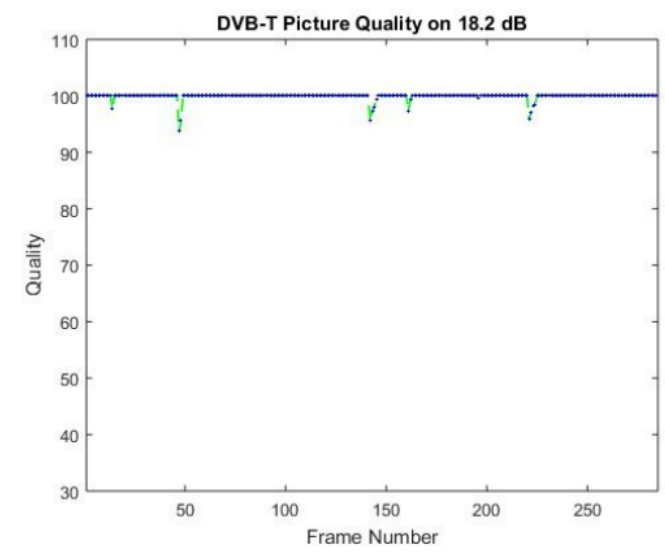


Gambar 13. quality verse frame number $(18.2 \mathrm{~dB})$

Gambar 13. ditampilkan hasil kualitas feedback frame number $18.2 \mathrm{~dB}$. Kualitas video yang dialirkan mengalami peningkatan yang signifikan. Hanya ada 6 kelompok kualitas visual yang tidak 100 poin. Tapi secara keseluruhan, video streaming kualitas sudah bagus pada percobaan ini.

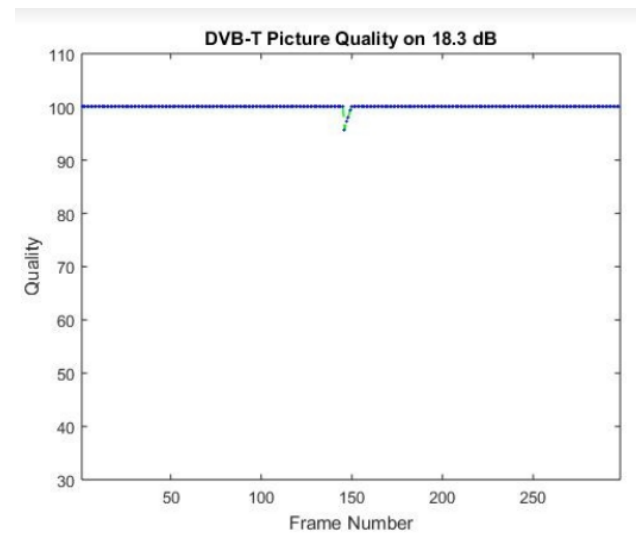

Gambar14. quality verse frame number $(18,3 \mathrm{~dB})$

Gambar 14. ditampilkan hasil kualitas feedback frame number $18.3 \mathrm{~dB}$. Kualitas video yang dialirkan hampir sempurna. Hanya ada 1 kelompok visual kualitas yang tidak 100 poin.

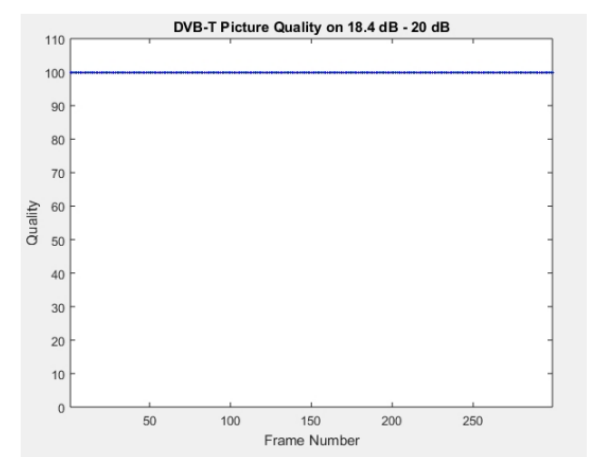

Gambar 15. quality verse frame number $(18,4 \mathrm{~dB}-20 \mathrm{~dB})$

Gambar 15. ditampilkan kualitas feedback frame number 18,4 dB - 20 dB. Hasil percobaan ini menunjukkan bahwa tidak terjadi kesalahan. Visual Hasil kualitas pada daya 18,4 dB hingga $20 \mathrm{~dB}$ sudah memiliki kualitas yang sangat baik. Di Pada kondisi ini, algoritma kendali daya adaptif akan bekerja untuk menyesuaikan dengan baik daya yang akan digunakan pada transmisi. Lebih banyak daya berarti lebih banyak biaya, jadi 18,4 dB lebih hemat karena kualitasnya sama dengan $20 \mathrm{~dB}$.

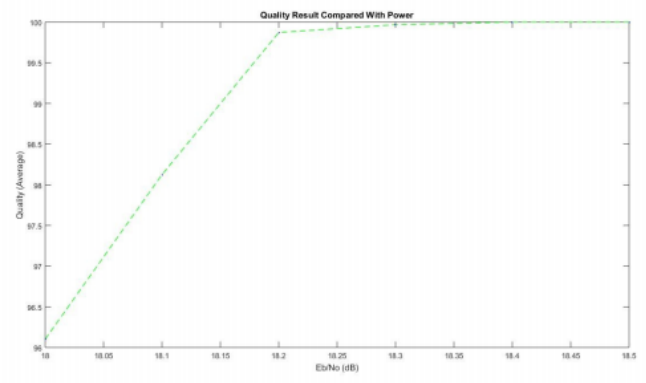

Gambar 16. Hasil Kualitas Dibandingkan dengan power

Gambar 16. menunjukkan semua kualitas rata-rata dari hasil simulasi dibandingkan dengan power yang digunakan pada setiap percobaan. Kualitasnya terus meningkat setiap peningkatan power. 


\section{Hasil Bit Error Rate (BER)}

Bit error rate (BER) pada setiap simulasi dapat dilihat pada gambar 17

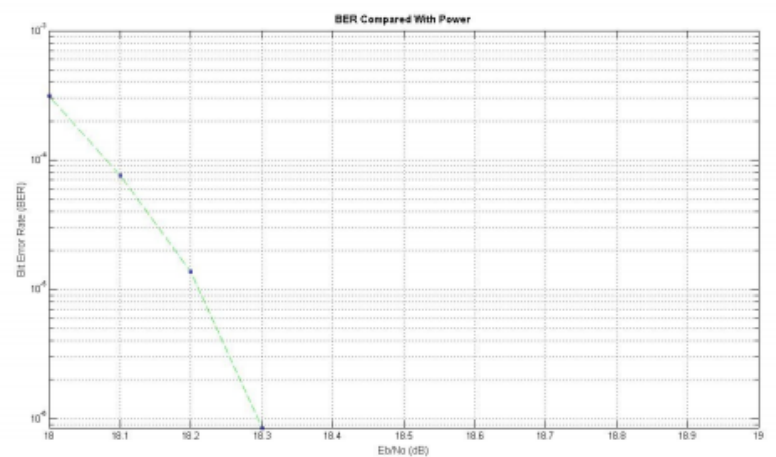

Gambar 17. Rata-rata BER VS Eb / No (dB)

Gambar 17. menunjukkan semua tingkat bit error rate (BER) dari hasil simulasi dibandingkan dengan power yang digunakan pada setiap percobaan. Tingkat kesalahan bit memiliki menurun pada setiap peningkatan power. Pada 18,4 dB dan lebih, data tidak terjadi kesalahan.

\section{Simulasi Menggunakan Adaptif Power Control}

Dalam percobaan simulasi ini menggunakan adaptif power control. Konfigurasi Simulasi menggunakan daya $18 \mathrm{~dB}$, karena memiliki banyak kualitas buruk hampir pada setiap frame. Simulasi ini dilakukan untuk menganalisis kemampuan adaptif power control. Hasil simulasi dapat dilihat pada gambar 18 .

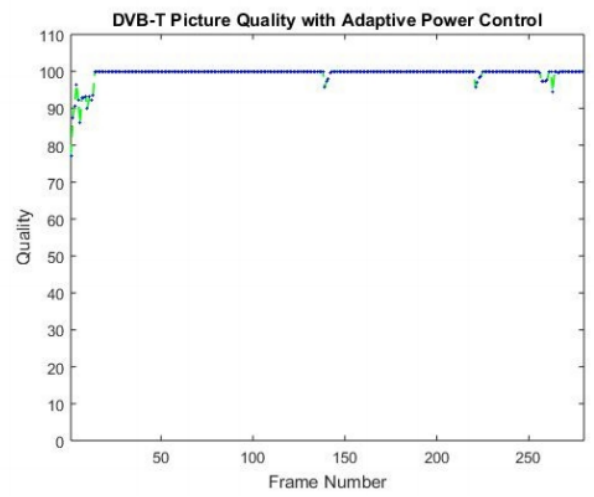

(a)

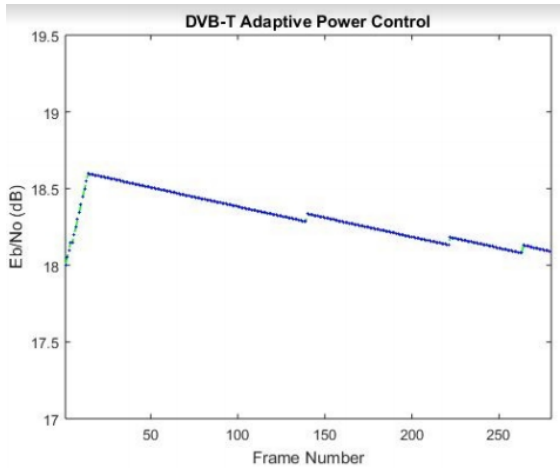

(b)

Gambar 18. Hasil Simulasi Kontrol Daya Adaptif

(a) frame VS Quality

(b) Eb / No (dB) verses Frame Number 
Gambar 18. menunjukkan hasil percobaan ini. Kualitas visual pada gambar 4.9 (a) sudah memiliki kualitas yang sangat baik. Ada 4 kelompok kualitas visual yang buruk karena program diatur untuk menurunkan daya ketika kualitas sudah ada kualitas yang baik. Pada percobaan kali ini penurunan daya tidak ada yang minimal treshold, itu dirancang untuk membuat sekelompok kesalahan ketika mencapai daya pemicu rendah mengadaptasi kontrol daya untuk meningkatkan daya. Gambar 4.9 (b) menunjukkan adaptif respons daya sesuai dengan umpan balik kualitas visual. Saat itu memiliki kualitas visual $<96$ (kualitas buruk) daya akan ditingkatkan untuk meningkatkan kualitas video yang diterima, sebaliknya bila kualitas visual antara 96 hingga 100 (kualitas baik) kekuatan akan diturunkan untuk menghemat biaya daya..

\section{KESIMPLAN DAN SARAN}

Kesimpulan dari penelitian ini adalah,

1) Hasil simulasi menunjukkan bahwa kualitas video yang buruk hanya terjadi pada power di bawah 18,4 dB. Pada $18 \mathrm{~dB}$, video yang di-streaming memiliki kualitas yang hampir buruk setiap frame, pada $18.1 \mathrm{~dB}$ ada beberapa kualitas yang sangat buruk pada beberapa frame Tapi kualitas video lebih bagus, hasil daya $18,2 \mathrm{~dB}$, jelek Kualitas hanya terjadi pada beberapa kelompok frame, pada daya 18,3 dB hamper sempurna karena hanya satu kelompok yang berkualitas buruk. Daya pancar masuk Sistem DVB-T menentukan kualitas video yang diterima. Tingkat kesalahan bit juga telah berkurang pada setiap peningkatan kekuatan yang berarti lebih tinggi kekuatan yang diberikan, berarti kualitas video yang lebih baik.

2) Nilai kualitas visual dikirim kembali ke pemancar melalui umpan balik saluran untuk perbandingan dengan kualitas referensi. Untuk mendapatkan keseluruhan kualitas, kualitas digunakan oleh algoritma kontrol daya untuk memutuskan apakah untuk meningkatkan daya atau menurunkan daya berdasarkan kualitas visual ambang batas.

3) Dengan menggunakan umpan balik kualitas visual, sistem yang dirancang dapat mengetahui pengguna pengalaman pada kualitas video yang diterima dan menggunakannya sebagai kekuatan berbasis PQ adaptasi. Hasil kontrol daya adaptif ditunjukkan saat kualitas di bawah 96 poin, daya akan ditingkatkan sebesar $0,05 \mathrm{~dB}$ ke meningkatkan pengalaman kualitas visual. Sebaliknya, saat umpan balik visual berikan sama atau lebih dari 96, daya akan dikurangi untuk menghemat daya biaya. Kontrol daya adaptif memberikan hasil yang baik secara signifikan menurunkan jumlah kualitas visual yang buruk pada simulasi saat menggunakan $18 \mathrm{~dB}$ kekuasaan. Ambang 96 dipilih karena saat gambar memiliki visual kualitas lebih dari 96, kualitas gambar dalam kondisi baik (dapat diterima) berdasarkan persepsi manusia. Sebaliknya, ketika kualitas visual kurang dari 96, kualitas gambar dinilai oleh pengguna sebagai kualitas yang tidak dapat diterima.

\section{REFERENCES}

U. Reimers, "Digital Video Broadcasting (DVB) the future of television," Physics World, April 1998.

ETSI, EN. 300468 V1.7.1 2006-05: European Standard (Telecommunications series) Digital Video Broadcasting (DVB). Specification for Service Information (SI) in DVB systems.

Dumic, E., Grgic, S., \&Sisul, G. 2010, September. Simulation model for the evaluation of DVB-T system parameters. In ELMAR, 2010 PROCEEDINGS (pp. 225230). IEEE.

ETSI, TR. 101190 V1.3.1 2008-10: Technical Report. Digital Video Broadcasting (DVB). Implementation guidelines for DVB terrestrial services. Transmission aspects

T. M. Kusuma, “A Perceptual-based Objective Quality Metric for Wireless Imaging," Ph.D. dissertation, Dept. Elect. and Comput, Eng., Curtin University of Technology., Australia, 2005.

MATLAB. [Online]. Available: http://www.mathworks.com/products/matlab/features.html 